\title{
Exploratory Factor Analysis of Pre-Purchase Construct for Airlines e-Ticketing System in Malaysia in The context of e-Transaction
}

\author{
Nor Alina Ismail ${ }^{1}$, Siti Norbaya Daud ${ }^{2}$ \\ ${ }^{1}$ School of IT, SEGi University, Malaysia, noralinaismial@ segi.edu.my \\ ${ }^{2}$ School of IT, SEGi University, Malaysia, norbayadaud@ segi.edu.my
}

\begin{abstract}
The use of technology is growing fast and most of industries apply technology in their business. The changes of technology usage has forced airline companies in Malaysia into intense competition among them. E-ticketing system will help to ease customers and companies in doing purchasing ticket electronically. In view of this situation in Malaysia, a measuring instrument was developed and assessed for reliability using the Exploratory Factor Analysis (EFA) procedure. Quantitative data was collected from 508 responses who had experience using airlines e-ticketing system in Malaysia using questionnaire survey. This study highlighted in detail Exploratory Factor Analysis process for Pre-purchase stage in online transaction cycle.
\end{abstract}

Key words: e-ticketing system, EFA, transaction cycle, Pre-purchase construct

\section{INTRODUCTION}

The Internet now occupies an important aspect of our daily lives; for being a source of important to get the information sources, competition in that all traditional media, and it was possible to create a new space can be invested for the marketing of certain products and services [10]

By implementing an e-ticketing website, the airlines is able to reduce a labor budget and this system also will improve company's profit [1]. Flight ticket system is used to represent the purchase of a seat on customer airlines normally using a website or any electronic kiosk [2]. The majority of airline companies in Malaysia choose a website and electronic kiosk as a platform to interact with their customer in order to increase the business value. Airline e-ticketing system is gaining attractiveness vastly compared to other e-shopping system because can give many benefits to company as well as customer [3]. Like other parts of world, the airline industry in Malaysia also affected by the current trends.

In this paper, pre-purchase construct in online transaction will be measured. The factors included was website design, search capabilities, price, promotions and loyalty program.
By considering implication of previous studies in the related literature, the development of research framework was self-developed to measure pre-purchase features in the context of online transaction stage among any Malaysia airlines e-ticketing systems customers.

\section{LITERATURE REVIEW}

This section presents a review of literature related to airlines e-ticketing system and e-transaction cycle in the Malaysian context.

\subsection{Airline e-ticketing websites.}

The travel resource in Malaysia already support significant industry based on moving domestic and international tourist to and with Malaysian and serving their requirements at its main tourist destination customer [3]. An e-Ticketing system can be defined as "a combination of issue and delivery the ticket from a single operation. E-ticketing system is an electronic document without a physical paper" $[1,2]$.

Like other countries, airline companies in Malaysia face aggressive competition due to globalization and rising customer demands. With that, the use of IT services play an important role in the strategic and operations management of airlines companies, as well as in facilitating the success of airlines business in the future. Therefore, to provide the requirements of both international and local tourists, most of airlines systems operations have been established with permits to operate purchasing flight ticket online. Most of successful airline companies in Malaysia have implemented this e-ticketing systems as their platforms for selling tickets starting in $2005[1,4$,$] .$

Based on statistic in 2018, nearly $80 \%$ of internet user bought flight ticket online [2]. This approach can helps the companies to increase its popularity on internet and also minimize the cost. The past study shows that basic knowledge is necessary to run the airline industry's complex daily operations whereas specific knowledge is imperative for airline competitive advantage especially in MAS and Air Asia. 


\subsection{Online Transaction Cycle.}

An e-transaction cycle fall into three major stages which are pre-purchase, purchase and post-purchase features [8].

Pre-purchase is one of the activities like searching an information about the product or how to purchase product online if customer is not familiar doing online transaction including the information about the price as agreed by Uma and Srivinasa [9]. They explained, pricing is very important for the planning especially for communication using online platform [9]. During this stage, basically company will attract customer by giving them a discount and promotion about their product. Besides, customers will get more information on the websites. While Purchase or at-purchase stage where customer come out with their own decision to completing this online purchasing process. Past study was highlighted that security and privacy as an important features in this stage because security and privacy will effect customers' decision [3].Last stage is post-purchase stage is where customer service will play their role as they need to make an online assessment to customer so that company will know about level of customer satisfaction and feedback after purchase a product [8]

In this paper only pre-purchase construct will be discussed and presented the EFA result.

\section{INSTRUMENT DEVELOPMENT}

The conceptualization of pre-purchase factors for this instrument derived from the past studies especially on Alhiou et. al [3]. After in-depth review of different sources and proposing several items for measuring pre-purchase features, the questionnaire instrument for the study was developed. To ensure content validity, the instrument was presented to the experts in the field; with the objective of eliminating any doubt or imprecise words from questionnaire [8]. The questionnaire content was developed in the light of purpose of the study and primarily involved experts as well as business materials on the aspects considered important in the context of airline industry. The questionnaire was designed in English to accommodate the majority of both Malaysian and non-Malaysian target sampling.

A structured questionnaire was developed for data collection to measure pre-purchase features which consist 16 items measured using seven point Likert-scale. The Likert-scale used was: $1=$ Strongly Disagree, $2=$ Disagree, $3=$ Slightly Disagree, $4=$ Neutral, $5=$ Slightly Agree, $6=$ Agree and $7=$ Strongly Agree. Table 1 shows the descriptive analysis for Pre-purchase construct. Data were analysed using SPSS tool version 22.
Table 1: Descriptive analysis for Pre-Purchase features.

\begin{tabular}{|c|c|c|c|}
\hline Construct/ Items & Code & Mean & $\begin{array}{l}\text { Std. } \\
\text { Dev }\end{array}$ \\
\hline \multicolumn{4}{|l|}{ Website design } \\
\hline The design of website is attractive & WD1 & 6.24 & 1.01 \\
\hline $\begin{array}{l}\text { The website information is always } \\
\text { updated }\end{array}$ & WD2 & 6.29 & 0.94 \\
\hline The websites has fast loading page & WD3 & 5.95 & 1.2 \\
\hline \multicolumn{4}{|l|}{ Search Capabilities } \\
\hline $\begin{array}{l}\text { It is easy to search all flight schedules } \\
\text { on the websites }\end{array}$ & SC1 & 6.08 & 1.08 \\
\hline $\begin{array}{l}\text { The search function is fast and } \\
\text { convenient }\end{array}$ & SC2 & 6.02 & 1.9 \\
\hline It is easy to search the ticket prices & SC3 & 6.08 & 1.06 \\
\hline \multicolumn{4}{|l|}{ Price } \\
\hline $\begin{array}{l}\text { The ticket prices are clearly stated on } \\
\text { the website }\end{array}$ & P1 & 6.11 & 1.05 \\
\hline $\begin{array}{l}\text { There are multiple choices of prices } \\
\text { available on the website }\end{array}$ & P2 & 6.09 & 1.08 \\
\hline $\begin{array}{l}\text { I can choose ticket prices based on my } \\
\text { financial plan }\end{array}$ & P3 & 5.99 & 1.13 \\
\hline \multicolumn{4}{|l|}{ Promotions } \\
\hline $\begin{array}{l}\text { The websites always show } \\
\text { promotional advertisement }\end{array}$ & Pro1 & 6.03 & 1.11 \\
\hline $\begin{array}{l}\text { I regularly read promotional } \\
\text { advertisements to compare with other } \\
\text { e-ticketing websites before making a } \\
\text { purchase }\end{array}$ & Pro2 & 5.00 & 1.6 \\
\hline $\begin{array}{l}\text { I am satisfied with the promotional } \\
\text { activities offered by the website }\end{array}$ & Pro3 & 5.77 & 1.1 \\
\hline $\begin{array}{l}\text { By reviewing a promotion, I do not } \\
\text { spend more money }\end{array}$ & Pro4 & 5.85 & 1.2 \\
\hline \multicolumn{4}{|l|}{ Loyalty program } \\
\hline $\begin{array}{l}\text { I can collect point every time I } \\
\text { purchase flight tickets with a loyalty } \\
\text { programme provided by airline } \\
\text { companies }\end{array}$ & LP1 & 6.30 & 1.58 \\
\hline $\begin{array}{l}\text { I can redeem free tickets if my loyalty } \\
\text { points reach the target }\end{array}$ & LP2 & 6.33 & 1.65 \\
\hline \multicolumn{4}{|l|}{ Overall items for Pre-purchase } \\
\hline $\begin{array}{l}\text { I am happy enough with the } \\
\text { pre-purchase process provided by the } \\
\text { airline company }\end{array}$ & & 6.17 & 1.19 \\
\hline Average mean & & 6.02 & \\
\hline
\end{tabular}

(Source: Nor Alina Ismail \& Husnayati Hussin, 2018)

Based on the Table 1, 5 constructs and 16 items used for this study. Among the 16 items of construct, 3 items belong to website design, 3 items belong to search capabilities, 3 items belong to price, 4 items belong to promotions, 2 items belong to loyalty program and 1 item is to measure the overall pre-purchase stage.

This finding indicate that most of the respondents are satisfied using all the services including searching an information about the flight schedule during pre-purchase stage. This result obtained 6.02 mean for the whole process in the pre-purchase. This result found that customers were happy using loyalty program that offered by the company and for customers this program is one of the special promotion offered by companies. This finding was similar with past study of Bayambaa and Chang [5]. For the airline companies' benefits, this will help to improve the staff development especially the top level of management. 


\section{RESEARCH METHODOLOGY}

A survey methodology involving face-to-face and online platform was employed to collect a data from respondent. The data collection activity was conducted in the area of Peninsular Malaysia including the KLIA, shopping malls and other public areas. The respondents were those using e-ticketing systems of any Malaysia airlines, Malaysians and Non-Malaysians. A total 508 of random sampling respondents participated in this study. The Cronbach alpha value for pre-purchase obtained as 0.76 which indicate high reliability. Many researches were influenced by Alhaiou [3] where established guidelines and were reported and serve as guidelines for measuring particularly pre-purchase features in online transaction cycle in the context of e-shopping.

This study is to develop a valid and reliable measure for pre-purchase constructs among customer in Malaysia specifically those had experience using any Malaysia airlines e-ticketing systems. Data collected using online questionnaire and also paper based questionnaire distribution.

\subsection{Exploratory Factor Analysis (EFA)}

Exploratory Factor Analysis (EFA) is a generally applied statistical technique in the social science [6] study. EFA can be defined as "a multivariate statistical procedure applied to reduce larger number of factors into smaller set of factors, establishes dimensions and provides construct validity to name a few [6]". The researcher adapted the instruments from previous studies since the context of this study is a bit different from previous study, the researcher modified some items in order to fit the current study. Based on Hair [6] explanation, if the researcher adjusted the instruments previously modified the statements to fit the current study, the researcher need to conduct the EFA procedure.

In this study, Kiser-Meyer-Olkin (KMO) and Bartlett's test were conducted to determine sampling adequacy. Bartlett's test should be significant at $<0.05$ for the factor analysis to be appropriate. The KMO ranges is from 0 to 1 but the general acceptance index is over 0.6. The total variance explained was also examined as an extraction process of items to reduce them into a manageable number before further analysis. In this process, items with eigenvalues exceeding 1.0 are extracted into different components. Rotated component matrix was examined and only items with a factor loading above 6.0 were retained for further analysis [6].

\subsection{Results of EFA}

Exploratory factor analysis is a statistical technique used to reduce data to a smaller set of variables. Tables 2 shows that the EFA procedure has extracted two components. In this study, only factor loadings above 0.5 will be retained.
Table 2: EFA for Pre-Purchase

\begin{tabular}{|l|l|l|l|}
\hline Code & F1 & F2 & F3 \\
\hline SC2 & .849 & & \\
\hline SC1 & .813 & & \\
\hline SC3 & .804 & & \\
\hline WD3 & .791 & & \\
\hline P1 & .707 & & \\
\hline WD2 & .702 & & \\
\hline WD1 & .595 & & \\
\hline P2 & .593 & & \\
\hline LP2 & & .912 & \\
\hline LP1 & & .912 & \\
\hline Pro2 & & & .768 \\
\hline Pro4 & & & .590 \\
\hline P3 & & & .582 \\
\hline Pro1 & & & .572 \\
\hline Pro3 & & & .534 \\
\hline
\end{tabular}

(Source: Nor Alina Ismail and Husnayati Hussin, 2018)

As displayed in Table 2, the pre-purchase items were loaded into three factors. WD1, WD2, WD3, SC1, SC2, SC3, P1, and P2 were loaded into factor 1, while LP1 and LP2 loaded into factor 2, all Pro1, Pro2, Pro3, and Pro4, and P3 was loaded into factor 3. Factor 1, factor 2, and factor 3 were renamed website features, loyalty program, and promotion. It is interesting to note that although P3 was posited to be categorized as Price, the result of EFA did not support this view. In fact, it was loaded into factor 3 , which indicated that they should measuring promotion instead of price.

The website features of each airline e-ticketing website must include the elements of website design, searching an information, pricing and also the promotions [4, 5]. The elements of website design were included attractive, interactive and informative. This three main elements also apart of how easy customer can seek an information which including seeking about the travel and destination, flight schedule or availability, frequent flyer information, an online entertainment and pricing and promotions information.

While the KMO and Bartlett's Test results of the study is presented in Table 3 as follow:

Table 3: KMO and Bartlett's Test for Pre-purchase

\begin{tabular}{|l|c|}
\hline $\begin{array}{l}\text { Kaiser-Mayer-Olkin Measure of Sampling } \\
\text { Adequacy }\end{array}$ & .898 \\
\hline Bartlett's Test of Sphericity & 4668.3 \\
\hline
\end{tabular}

(Source: Nor Alina Ismail and Husnayati Hussin, 2018)

The general acceptance index of KMO is over 0.6. Table 3 shows the KMO value of 0.898 is excellent as it exceeds the recommended value of 0.6. The significance value of Bartlett's Test of Sphericity must less than 0.05 for the factor analysis to be acceptable. The Bartlett's test significance value is 0.000 which meet the required significance value of less than 0.05 [8]. Therefore, KMO value is very close to 0.9 / 1 at the significance level of 0.000.This result implying factors analysis was suitable and significant. 


\section{CONCLUSION}

Nowadays, the virtual community has been considered as an important standard for attracting and maintaining long term relationship with customers. Thus many companies for improving their performance need to put the e-shopping and e-purchasing situation in the centre of their focus.

As a conclusion, this study examined the measurement of Pre-purchase factor including website design, search capabilities, price, promotion and loyalty program, particularly in the context of Malaysia airlines e-ticketing systems. The EFA result of the study produced a structure extracted 3 constructs instead of 5 constructs or new constructs of Pre-purchase namely website features, loyalty program and promotion.

These constructs been measured by 16 items developed in this study for pre-purchase factor. The reliability measures for the three dimensions of pre-purchase construct showed very high Cronbach's Alpha value which is 0.888 , Bartlertt's Test achieved the significance value while KMO is above 0.6. Most of factors loading was exceed the minimum threshold of 0.5. This reflect that all the items are applicable for this research. The scale development and validation procedures of the current study have ensured that the new pre-purchase instruments is internally consistent and stable across sample of study.

\section{REFERENCES}

[1] Ainin, S., Josephine, N., \& Suhana, M. E-ticketing in Malaysia: Usage Trends. The $10^{\text {th }}$ Pasific Asia Conference on Information System (PACIS, 2006). pp 68-82, 2016.

[2] Ainin, S., Josephine, N., \& Suhana, M. E-tieckting as a New Way of Buying Tickets: Malaysian Perceptions. Journal of Social Science, Vol. 17(2). pp. 149-157, 2008 https://doi.org/10.1080/09718923.2008.11892644

[3] Alhaiou, T. An Empirical Study on Electronic Customer Relationship Management (E- CRM) Implementation and E-loyalty at Different Adoption Stages of Transaction Cycle. (Published PhD's Thesis). United Kingdom: University of Brunel, 2011 https://doi.org/10.1504/IJLSM.2012.045427

[4] Benjamin, C.Y.F., Aw, Y.C., \& Damoon, Y. An Exploratory of Airline E-Ticket Purchasing Intention Among Foreign Undergraduates in Malaysia. Journal of Human and Social Science Research. Vol. 1 (1), pp. 51-61, 2003.

[5] Byambaa,B. \& Chang, K.C. The Influence Factors of Online Purchase on Customer Satisafction in Mongolian Airlines. Vol.57(15), pp. 80-85, 2012.

[6] Hair, J.F., Anderson, R.E., Tatham, R.L., \& Black, W.C. Multivariate Data Analysis, 7th, Prentice Hall, Englewood Cliffs, New Jersey, 2010.
[7] Home Page of Travel and Tourism. Retrieved September 14, 2015, from http://www.travelandtourism.com/ 20030731/cover.shtml, 2015

[8] Hogarty, K , Hines, C, Kromrey, J, Ferron, J, \& Mumford, K. The Quality of Factor Solutions in Exploratory Factor Analysis: The Influence of Sample Size, Communality, and Overdetermination. Educational and Psychological Measurement, 65(2), 202-226, 2005. https://doi.org/10.1177/0013164404267287

[9] Uma Maheswara, K., \& Srinivasa Rao, T.Y. Communication Networks Based on Price Difference. International Journal of Advanced Trends in Computer Science and Engineering (WARSE). Vol.3, No.5, 158-163, 2014.

[10] Mohammed Abdullah Al Qahtani. Social Networking Application in the Saudi Arabian Airlines Company: Explority Study. International Journal of Advanced Trends in Computer Science and Engineering (WARSE). Vol.5, No.4, 21-32, 2016. 